\title{
DESCONSIDERAÇ̃̃̃O DA SOCIOAFETIVIDADE E DESPROTEÇÃO À INFÂNCIA: REGULAÇÃO E DISCURSO JURÍDICO SOBRE A PATERNIDADE
}

\author{
DISRESPECT OF THE SOCIO-AFFECTIVITY AND DEPROTECTION TO CHILDHOOD: \\ REGULATION AND JURIDICAL SPEECH ABOUT PATERNITY
}

\section{RESUMO}

Verdade registral, biológica ou socioafetiva, qual prevalece diante de conflito no caso concreto? A partir do direito constitucionalmente assegurado às crianças e adolescentes à prioritária proteção de seus interesses, pergunta-se sobre quais os efeitos da desconsideração da socioafetividade na determinação jurídica da paternidade. Percebeu-se que no discurso Jurídico, em dois recursos distintos, julgados no Superior Tribunal de Justiça em 2015, posições divergentes coexistiram quanto aos critérios de determinação da paternidade. Algumas categorias nortearam a discussão: flexibilidade de alteração dos Registros de Nascimento, vontade e voluntariedade na manutenção do vínculo paterno, provisão de alimentos para sustento do filho, espontaneidade no registro via 'adoção à brasileira', 'traição' feminina caracterizando o 'erro' que autoriza a Negatória de Paternidade, culpabilização da mulher e proteção à honra subjetiva do homem traído. Observou-se o confronto entre interesses incompatíveis: o do homem de desobrigar-se da parentalidade versus o do filho de ter seu status de filiação preservado.

Palavras-chave: Discurso Jurídico. Socioafetividade. Melhor interesse da Criança.

\begin{abstract}
Registral, biological or socio-affective truth, which one takes advantage in the conflict case concrete? From the constitutionally law assured to children and teenagers to the with priority protection of their interests, it is asked which effects of the disrespect of the socio-affectivity in the legal determination of the paternity are. It was noticed that, in two distinct resources, judged in the Superior Court of Justice in 2015, divergent positions had coexisted about the criteria of deconstitution of the paternity. Some categories had guided the quarrel: flexibility of alteration of the Birth certificate, voluntariness in the maintenance of the paternal bond, food provision and sustenance of the son, spontaneity in the register saw "adoção à brasileira" (peculiar way that Brazilians use in order to 'adopt' a child), 'feminine treason' characterizing 'mistake' that authorizes the Negatory of Paternity, scapegoating of the woman and protection to the honor of the betrayed man. The confrontation between incompatible interests was observed: of the man to release itself of the parental paper versus the one of the son to have its status of preserved filiation.
\end{abstract}

Keywords: Paternity. Legal speech. Socio-affectivity. Better interest of the Child.

Mariana Sarmento Lira

Universidade Federal de Pernambuco (UFPE). E-mail: marianaslira@hotmail.com

Luis Felipe Rios do Nascimento

Universidade Federal de Pernambuco (UFPE). E-mail: Ifelipe.rios@gmail.com 


\section{Introdução}

O Direito brasileiro consagrou e elevou à categoria de 'princípio jurídico' a consideração do 'melhor interesse da criança' nas ações das Varas das Famílias e da Infância em que figuram crianças e adolescentes. A respeito do contexto de surgimento desta categoria principiológica, documentos fruto de convenções internacionais possuem relevância e destaque. Isto porque, uma vez ratificados pelo Estado brasileiro, tais convenções e tratados passaram a reconhecer crianças e adolescentes como sujeitos de direitos, fazendo com que os estados membros se comprometessem a assegurá-los cuidado, respeito e prioritária proteção.

Foram criados importantes documentos internacionais que asseguravam os direitos das crianças, como a Declaração dos Direitos das Crianças de 1959, as Convenções da OIT, a Declaração de Genebra - Carta da Liga sobre a Criança de 1924, além da Convenção Interamericana de Direitos Humanos (Pacto de San José da Costa Rica). Passou-se, então, a considerar as crianças não mais objetos, mas sujeitos de direito, que mereciam proteção da família, da sociedade e do Estado para se desenvolverem física e psicologicamente. Foram assegurados às crianças, aos adolescentes e aos jovens (EC 65/2010) os direitos humanos fundamentais. ${ }^{1}$

No Brasil, marcos legais como a Constituição Federal de 1988, em seu artigo 227, e o Estatuto da Criança e do Adolescente também foram relevantes para que a Doutrina da Proteção Integral se estabelecesse. De acordo com o estabelecido na Constituição Cidadã, passava a ser responsabilidade da família, do Estado brasileiro e da sociedade, prover com absoluta prioridade, os direitos das crianças e dos adolescentes, os quais deveriam estar à salvo de toda e qualquer forma de negligência, discriminação, exploração, violência, crueldade e opressão.

Dentre os direitos protegidos pelo legislador constituinte, restou assegurado o direito à convivência familiar enquanto direito fundamental. No entanto, destacase que houve mudanças no que se entende por família e que o amparo normativo às novas configurações familiares nem sempre existiu:

[...] no Código Civil de 1916, o conceito de família era centrado no instituto do casamento com a 'distinção odiosa' entre filhos legítimos, legitimados e ilegítimos, com a filiação baseada na rígida presunção de paternidade do marido. [...] o paradigma não era o afeto entre familiares ou a origem biológica, mas apenas a centralidade do casamento. Porém, com a evolução no campo das relações familiares, e a aceitação de novas formas de união, o eixo central da disciplina da filiação se deslocou[... ${ }^{2}$

\footnotetext{
1 (Silveira, 2011, p. 2)

2 (Cassettari, 2017, p.191)
} 
Restrita aos laços indissolúveis do matrimônio, refém da consanguinidade e presa a arranjos negociais, a família era fortemente hierarquizada e patriarcal. Na antiga configuração, mulher e prole ocupavam necessariamente lugares de sujeição e inferioridade, assombrados pelo controle e pela vigilância da autoridade dos 'chefes de família'.

Ocorre que, em decorrência das mudanças sociais, com o passar do tempo, as uniões entre os casais passaram a se caracterizar como parcerias eminentemente afetivas, as quais, muitas vezes, têm se organizado enquanto famílias sem a tutela da igreja ou a chancela do estado. Tratam-se de famílias fundadas em alicerces mais plurais e igualitários.

Como consequência destas transformações, atualmente, a legislação brasileira reconhece entidade familiar enquanto uma comunidade formada por indivíduos que são ou se consideram aparentados, unidos por laços naturais, por afinidade ou por vontade expressa (Brasil, 2006). Destaca-se que também compete a essa nova família, plural e igualitária, assegurar o melhor interesse da infância e da adolescência.

Ocorre que, quando essas famílias buscam a tutela estatal para a solução de seus conflitos e a determinação do dito 'melhor interesse no caso concreto', os operadores do Direito se utilizam dos saberes de outros campos de conhecimento, dentre os quais figuram a psicologia, a psicanálise, a psiquiatria, entre outros.

[...]a política do melhor interesse da criança e do adolescente prescreve ações cujos parâmetros são estabelecidos por saberes, entre os quais figuram a psicologia. Entre as ações prescritas, estão as práticas de cuidado e proteção, que têm a pretensão de possibilitar resguardar o desenvolvimento emocional sadio, harmônico, ajustado 3

Nesta perspectiva, convém anotar que o embasamento usado pelos operadores do Direito no ajuizamento dos pedidos de seus clientes, e, também os argumentos usados pelos magistrados nos julgamentos, ancoram-se em saberes de outros marcos epistemológicos. Discursos atravessados por expressões da antropologia, psicanálise, psicologia são incorporados a linha jurídico-argumentativa a fim de que se consiga chegar a definição do que seria o 'melhor interesse da criança' em cada caso. Foucault (2010) já havia refletido sobre o uso dos saberes 'psis' como estratégias de controle das subjetividades.

[...] onde se cruzam a instituição judiciária e o saber médico ou científico em geral, nesse ponto são formulados enunciados, que possuem o estatuto de discursos de verdade, que detêm efeitos judiciários consideráveis e que têm, no entanto, a curiosa propriedade de ser alheios a todas as regras, mesmo as mais elementares, de formação de um discurso científico; de ser alheios também às regras do direito e de ser, no sentido estrito, grotescos. ${ }^{4}$

\footnotetext{
3 (Amaral, 2013, p. 22)

4 (Foucault, 2010, p. 11)
} 


\section{Objetivo e Método}

No que diz respeito a entrada do paradigma da socioafetividade, no debate sobre a filiação no judiciário brasileiro, o tratamento do tema não tem sido unívoco. No presente trabalho, questiona-se se o Judiciário, diante da necessidade de aplicação do princípio do melhor interesse da criança, tem agido com coerência e linearidade nos casos em que se instaura o debate sobre a primazia da socioafetividade sobre a consanguinidade.

O objetivo desta investigação é refletir sobre o uso e a coerência dos sentidos atribuídos a expressão "melhor interesse da criança" nas ações em que compete ao Superior Tribunal de Justiça (STJ) julgar a prevalência da paternidade socioafetiva sobre a biológica. Para tanto, foram selecionados dois julgados: um pedido de Negatória Clássica de paternidade, advinda da aplicação do artigo 16o1 do código Civil de 2002, e uma Ação Anulatória de Falso Registro de Nascimento, também conhecida como pedido de Desconstituição da Paternidade Registral.

Neste ponto, faz-se necessária estabelecer a distinção entre estes dois tipos de Ações: as 'Negatórias Clássicas' (contestação de paternidade pelo marido da mãe, com base no artigo 1601 do Código Civil de $2002^{5}$ ) e as Anulatórias de falso registro (situações de 'adoção à brasileira' em que o marido/companheiro da mãe biológica da criança, registra o infante mesmo sabendo não ter vínculo biológico com ele, e, depois deseja desobrigar-se do reconhecimento estabelecido). No primeiro caso, trata-se de ação ajuizada por alguém que, por ser oficialmente casado com a mãe da criança ou viver em união estável com ela, à época do nascimento do filho, julgou que era o genitor de fato, pela presunção do dever de fidelidade recíproca e monogâmica do casamento civil, ou pela presunção de exclusividade da relação afetiva. No segundo caso, por sua vez, o pai registral sabia que não era o genitor biológico e mesmo assim efetuou o registro da criança.

Ainda sobre a distinção entre os dois tipos de ação, nas palavras de Portanova (2018, p.53), do ponto de vista da importância probatória do DNA nos dois tipos de ações, tem-se que, na negatória, o resultado negativo do exame é a prova do erro a que foi conduzido o homem traído e afasta a paternidade. Já na anulatória, como aquele que efetua o reconhecimento da paternidade o faz de modo voluntário e desacautelado, mesmo já sabendo que não é o genitor, o que o exame do DNA pode provar, não assume tanta relevância. É como se nesse último caso, o pai registral tivesse mais dificuldade em se desobrigar da paternidade quando comparado a situação em que figura o 'marido/companheiro traído' da mãe.

Considerando quea constituição determina como dever da família, da sociedade e do Estado assegurar à criança e ao adolescente à convivência familiar, perguntase sobre quais seriam os efeitos da desconsideração da socioafetividade no debate sobre a proteção ao melhor interesse da criança? Nas hipóteses de vínculo parental

5 O artigo 1.6or do Código Civil Brasileiro estabelece que: "Cabe ao marido o direito de contestar a paternidade dos filhos nascidos de sua mulher, sendo tal ação imprescritível” (Brasil, 2002) 
previamente registrado quais as consequências da descoberta posterior da ausência da paternidade biológica das Negatórias? Diante da controvérsia relativa à prevalência da socioafetividade sobre a paternidade biológica como tem decidido o STJ quando há conflito entre as duas?

Para tentar responder tais questionamentos e alcançar o objetivo proposto, foi realizado o estudo de documentos públicos, no sítio eletrônico do Superior Tribunal de Justiça (STJ), onde foram coletados dois julgados, do ano de 2015, dentre os tipos de ações anteriormente apontados, quais sejam: Negatória e Anulatória de paternidade. O trajeto percorrido no portal do STJ foi: primeiramente, acessando o link denominado 'Jurisprudência do STJ'. Em seguida, diante das opções de pesquisa por área de Direito, clicou-se em 'Direito Civil'. No critério de pesquisa foi utilizado o descritor 'filiação socioafetiva', onde pode ser encontrado outro link com o título 'adoção à brasileira, adoção unilateral e filiação socioafetiva' (http://www.stj.jus.br/ SCON/pesquisa_pronta/toc.jsp ). Neste último, as jurisprudências relacionadas ao presente tema estavam dispersas.

\section{Resgate dos Enunciados}

Aponta-se a primeira jurisprudência colhida do Recurso Especial (REsp 1.330.404-RS) de caso originalmente julgado em 05/02/2015 no Rio Grande do Sul, com o Ministro. Marco Aurélio Bellizze como relator, publicado no Diário de Justiça eletrônico em 19/2/2015. Trata-sede Negatória dePaternidadeajuizada pelo pai registral que, na constância da União Estável com a genitora da criança, reconheceu-a como filho. Destaca-se que o Superior Tribunal de Justiça julgou pela desconstituição de paternidade registral apesar da existência incontroversa de vínculo de socioafetividade por ininterruptos cinco anos entre aquele que figurava como pai registral e a criança.

$\mathrm{Na}$ fundamentação do julgado, o relator argumenta que apesar do ordenamento jurídico brasileiro respaldar a filiação socioafetiva, no caso concreto, além da necessidade de comprovação do estado de posse de filiação, segundo o qual a paternidade se constituiria pela fama ( notoriedade social no reconhecimento do filho), pelo tratamento público dado pelo pai ao filho e pelo nome paterno recebido no ato registral, haveria outro requisito a ser levado em consideração: a voluntariedade da manutenção do vínculo. Nas palavras do julgador:

Ocorre que o estabelecimento da filiação socioafetiva perpassa, necessariamente, pela vontade e, mesmo, pela voluntariedade do apontado pai, ao despender afeto, de ser reconhecido como tal. Em outras palavras, as manifestações de afeto e carinho por parte de pessoa próxima à criança somente terão o condão de convolarem-se numa relação de filiação se, além da caracterização do estado de posse de filho, houver, por parte do indivíduo que despende o afeto, a clara e inequívoca intenção de ser concebido 
juridicamente como pai ou mãe da criança. Portanto, a higidez da vontade e da voluntariedade de ser reconhecido juridicamente como pai consubstancia pressuposto à configuração de filiação socioafetiva no caso aqui analisado. (REsp 1.330.404-RS, Relator Ministro Marco Aurélio Bellizze, Terceira turma, julgado em 05/02/2015, DJe 19/02/2015)

No julgado em análise, quando pai descobriu que fora traído, a partir do resultado negativo do exame de DNA, decidiu voluntariamente se afastar do convívio da criança. Desta decisão, manteve-se distante de qualquer contato com o filho registral por oito anos e, em seguida, ajuizou pedido de Negatória de Paternidade. O argumento presente nas entrelinhas do julgado é que não se poderia obrigar um pai que, induzido a erro, registrou filho alheio como próprio, a nutrir afeto pela criança, sem sua vontade. Contudo, ao que parece, a voluntariedade do desinvestimento afetivo do pai em relação ao filho prevaleceu em detrimento da perspectiva do melhor interesse da criança, que sequer foi mencionado:

[...] sem proceder a qualquer consideração de ordem moral, não se pode obrigar o pai registral, induzido a erro substancial, a manter uma relação de afeto igualmente calcada no vício de consentimento originário, impondo-lhe os deveres daí advindos sem que voluntária e conscientemente o queira. Além disso, como a filiação socioafetiva pressupõe a vontade e a voluntariedade do apontado pai de ser assim reconhecido juridicamente, caberá somente a ele contestar a paternidade em apreço[...]. (REsp 1.330.404-RS, Relator Ministro Marco Aurélio Bellizze, Terceira turma, julgado em 05/02/2015, DJe 19/02/2015)

Destaca-se, a partir da leitura deste fragmento, a necessidade de problematizar a negativa de que considerações de ordem moral estivessem presentes naquele julgado. Ora, se os argumentos em debate diziam respeito a uma situação de omissão de informações, mentira, vício de consentimento no registro, repercussões da infidelidade da mulher com o autor e, sob certo aspecto, sobre a regulação do exercício da sexualidade feminina, como é possível excluir considerações de ordem moral?

Ademais, questiona-se se a mesma pré-condição da higidez de vontade e voluntariedade estaria presente em outras demandas judiciais em que se investiga a paternidade. Por exemplo, em situações em que o vínculo biológico é confirmado pelo resultado do exame de DNA, não há 'voluntariedade' do genitor, atuando como réu no processo, em assumir a função de pai, até porque, se houvesse, o reconhecimento teria sido efetuado espontaneamente, sem a necessidade de busca de provas quanto à filiação, tampouco da ingerência estatal na esfera privada dos envolvidos. Nestas hipóteses, confirmado o resultado do dito exame, tido como prova com níveis de certeza quase absolutas pelo judiciário, nada é mencionado no sentido de exigir vontade e voluntariedade do pai, que simplesmente é compelido a registrar o menor como filho, 
obrigatoriamente, sem nenhuma discussão a respeito da higidez de vontade, intenção de investimento afetivo ou voluntariedade na manutenção do vínculo. Prevalece, nestas hipóteses, o paradigma biológico. Assegura-se ao infante o nome do pai em seu Registro de Nascimento e a obrigação da prestação alimentar, todavia, ao que parece, nada pode ser dito sobre a voluntariedade afetiva dessa filiação, que poderá ser exercida somente pela força da decisão judicial.

Outro caso, originário de Minas Gerais, fruto do Agravo em Recurso Especial (AREsp 653643 MG 2015/ooo9919-o), julgado em 2015, com Ministro relator Raul Araújo, e, publicado no Diário de Justiça em 09/04/2015, também traz elementos relevantes a respeito das intervenções jurídicas no destino das crianças a partir da regulação do que se entende pelo seu melhor interesse. Trata-se, agora, de exemplo de Ação Anulatória de Paternidade, um caso de adoção à brasileira em que foi realizado o registro voluntariamente por quem já sabia que não havia vinculação biológica entre ele e o filho de sua companheira.

O recurso de Apelação cível do pai registral, que desejava deixar de figurar enquanto tal, teve como resultado da apreciação o seu desprovimento, apesar do autor do recurso ter argumentado pela anulação do registro, uma vez que não havia nem paternidade biológica, nem socioafetiva:

[...] Se as partes não controvertem quanto à inexistência da paternidade biológica e se revelado inequivocamente nos autos a inexistência de paternidade socioafetiva, inexorável concluir que o assentamento civil que a estampa não prestigia a verdade real, o que suficiente a seu desfazimento. (AREsp 653643 MG 2015/ooo9919-o, Relator Ministro Raul Araújo, DJe 09/04/2015)

No entender do relator, contudo, apesar da tese suscitada peloautor, configuravase a impossibilidade de anulação do Registro Civil visto que o reconhecimento havia sido realizado espontaneamente:

Não obstante a anulação do ato registral respectivo, o fato é impediente do direito à declaração de inexistência de vínculo parental entre as partes, pois o apelado é, sim, pai social da apelante, ao menos enquanto perdure a obrigação de lhe suprir alimentos, 'à míngua de prova da existência entre as partes de relações de outra natureza.' O acórdão objurgado não encontra amparo na orientação jurisprudencial desta Corte Superior, a qual entende pela impossibilidade de desconstituição do registro civil de nascimento quando o reconhecimento da paternidade foi realizado de forma voluntária por quem sabia não ser o pai da criança. (AREsp 653643 MG 2015/ooog919-o, Relator Ministro Raul Araújo, DJe 09/04/2015)

Quanto ao peso do afeto no debate, o relator apontou que este: 
[...] é elemento de consolidação da relação parental, mas sua ausência não a descaracteriza. 5. Só a extinção do vínculo afetivo entre pais e filhos não os exime das obrigações e direitos legais derivados do poder/dever familiar. 6. Ainda que não haja afeto, subsiste a relação de parentalidade social, fundada nos princípios constitucionais da dignidade humana e da paternidade responsável, orientados à preservação da família. 7. O dever de prestação de alimentos é expressão da paternidade social de que se investe aquele que voluntariamente reconheceu como próprio filho de outrem, ainda que ao arrepio do devido processo ('adoçãoà brasileira'). (AREsp 653643 MG 2015/ooo9919-o, Relator Ministro Raul Araújo, DJe 09/04/2015)

No caso em análise, o autor não pode facilmente se desobrigar da paternidade apesar da afirmação nos autos de haver demonstração inequívoca de inexistência de vínculo socioafetivo. A decisão do STJ foi a de manter a Paternidade no registro civil. Na fundamentação da decisão, o relator se utilizou de outro enunciado de jurisprudência, um terceiro julgado, segundo o qual:

DIREITO CIVIL. RECURSO ESPECIAL. FAMÍLIA. CRIANÇA E ADOLESCENTE. AÇÃO DE ANULAÇÃO DE REGISTRO DE NASCIMENTO. INTERESSE MAIOR DA CRIANÇA. AUSÊNCIA DE VÍCIO DE CONSENTIMENTO. IMPROCEDÊNCIA DO PEDIDO. 1. A prevalência dos interesses da criança é o sentimento que deve nortear a condução do processo em que se discute de um lado o direito do pai de negar a paternidade em razão do estabelecimento da verdade biológica e, de outro, o direito da criança de ter preservado seu estado de filiação. 2. O reconhecimento espontâneo da paternidade somente pode ser desfeito quando demonstrado vício de consentimento; não há como desfazer um ato levado a efeito com perfeita demonstração da vontade, em que o próprio pai manifestou que sabia perfeitamente não haver vínculo biológico entre ele e o menor e, mesmo assim, reconheceu-o como seu filho. [...] (REsp 1229044/ SC, Rel. Ministra NANCY ANDRIGHI, TERCEIRA TURMA, julgado em 04/06/2013, DJe 13/06/2013)

Ao que parece, ao utilizar como referência o entendimento citado neste último recorte, o julgador parece legitimar uma ressalva quanto aos critérios de determinação da filiação. É como se, uma vez configurado o critério 'vício de consentimento', a jurisprudência consentisse com uma relativização da consideração do princípio do melhor interesse da criança e do adolescente. De todo modo, em ambos os julgados é possível suscitar a discussão sobre a consideração do 'melhor interesse da criança' nos enunciados discursivos da jurisprudência brasileira sobre paternidade, por meio de relações de Poder e Saber que se atravessam neste campo. 


\section{Análise}

A leitura dos enunciados coletados na jurisprudência do STJ chamou a atenção pela descontinuidade do discurso jurídico quanto a menção/ omissão do princípio do melhor interesse da criança.

Um primeiro quesito fruto da reflexão sobre os julgados é que discurso jurídico, quandose utiliza da categoria principiológica do 'melhor interesseda criança' não possui um único referente. Nos argumentos apontados nos enunciados coletados denota-se a presença de algumas categorias analíticas. Destaca-se ainda que não há aplicação uniforme da expressão 'melhor interesse da criança' em todas as ações envolvendo crianças e adolescentes. $\mathrm{O}$ uso do princípio pode se dar, ou não, a depender do caso concreto. Quando comparamos a Anulatória e a Negatória, por exemplo, percebeu-se que não houve a aplicação homogênea do princípio, suscitando questionamentos, se com a omissão da proteção da infância pelo mencionado princípio estaria se dando ensejo a uma invisibilidade da perspectiva da criança sobre a manutenção ou extinção do vínculo de paternidade.

No exemplo de Negatória selecionado, permitiu-se tacitamente que, pelo vício no consentimento no momento do registo, e pela ofensa à honra subjetiva sofrida pelo cônjuge traído, este último pudesse se desobrigar do 'encargo' da paternidade. No caso em análise, aquele que exercia a paternidade de fato deliberadamente se ausentou da vida do filho ao tomar conhecimento do resultado do exame de DNA. Mais tarde, esse afastamento voluntário do pai recebeu proteção jurídica com a desconstituição da Paternidade via Negatória de Paternidade. Ou seja, percebeu-se que aplicação do princípio do melhor interesse da criança se evidenciou com uma lacuna, uma vez que sequer foi mencionado no julgado. O estudo dos enunciados suscitou ainda o debate sobre o conflito entre direitos: o do filho de ter preservado seu estado de filiação em oposição ao direito do pai de negar a paternidade em razão da ausência de vinculação biológica.

A criança-ré da anulatória tem mais direitos que a criança-ré da negatória. Na negatória, apesar de haver paternidade socioafetiva, a criança, de imediato, perde o pai, o nome, a proteção e os direitos patrimoniais. Na anulatória de falso registro, apesar de não haver paternidade socioafetiva, a criança permanece com o pai, o nome, a proteção e os direitos patrimoniais. ${ }^{6}$

Também chamou a atenção o peso da 'verdade biológica', como é designada, e seu amparo na cientificidade do exame de DNA nas Negatórias, uma vez que a simples demonstração do resultado negativo da perícia genética já funciona como forte indício de 'erro', significando o engano do companheiro ou esposo traído. Demonstrado a hipótese de tal 'erro', configura-se a justificativa que, por si só, já se mostra suficiente

6 (Portanova, 2018, p. 148) 
para a retificação do Registro de Nascimento da criança e do adolescente, sem que sequer o princípio em análise nesta discussão tivesse sido mencionado.

Também foi notável distinção entre o peso da 'verdade do Registro', pela rigidez e dificuldade em retificá-lo na Anulatória versus a flexibilidade em modificálo na Negatória. Nesta última, o assento de nascimento pode ser modificado mais facilmente, com a ausência do vínculo biológico, comprovada pelo exame de DNA, e, pela demonstração de que houve erro ou vício de consentimento. Neste caso, nada se argumentou sobre a necessidade de preservação da verdade documental, nem sobre a segurança jurídica indispensável à vida em sociedade. Diferentemente ocorreu na Anulatória, sob o argumento de que, pelo fato da declaração da paternidade ter se realizado de maneira voluntária e ter sido investida das formalidades sociais inerentes aos registros públicos cartorários, a paternidade não poderia ser desconstituída.

Outro ponto que merece destaque é que nas Ações Negatórias, instaura-se o debate a respeito da perspectiva moralista do Direito acerca do 'adultério feminino' e da 'culpa' que recai sobre a mulher quanto ao fato de o registro paterno estar em desconformidade com a verdade biológica. Neste ponto, as questões de gênero se entrelaçam ao debate sobre o discurso jurídico da paternidade, pela percepção de que este se constitui como um dispositivo de controle, vigilância e punição do livre exercício da sexualidade feminina. Tudo isso, em defesa da 'honra subjetiva do cônjuge' traído, categoria que, até alguns anos, encontrava amparo na lei e na jurisprudência brasileira.

Até o ano de 2002, o adultério era considerado um crime. Como esse delito atingia a família e a honra do cônjuge traído, o Código Penal, em seu artigo 25, estabelecia que o cônjuge traído poderia valer-se da legítima defesa da honra e da moral para amparar atos praticados contra o parceiro infiel e seu amante ${ }^{7}$

De acordo com Portanova (2018, p.157) em uma ação de desconstituição da paternidade por meio da Negatória Clássica se permite uma "induvidosa ingerência do Estado na vida da mãe”, ademais, sobre a mulher recairá uma espécie de penalização pela 'infidelidade' sofrida pelo homem que se estende de maneira cruel aos filhos. Nessa ação é como se o Estado permitisse ao homem se vingar daquilo que culturalmente tanto afeta a sua masculinidade: a traição conjugal, e, nessas situações, a tutela jurídica da honra do homem traído será garantida mesmo que, sejam negligenciados os vínculos socioafetivos já estabelecidos entre o pai registral e a criança.

Neste ponto, vale refletir sobre o impacto do uso irrestrito da tecnologia do exame do DNA no cotidiano das Varas de Família. Isto porque, se por um lado o recurso da tecnologia genética "pode ser usado para firmar um laço de parentesco, por outro lado, pode ser usado para negar laços já existentes” ${ }^{8}$

7 (Amaral, 2013, p. 32)

8 (Fonseca, 2004, p.15) 
Considerando o posicionamento de doutrinadores em Direito de Família (Dias, 2017; Lôbo, 2010; Pereira, 2012), em tese, a identificação de quem que exerce a paternidade socioafetiva, por seu turno, também pode influenciar o desfecho de uma ação Anulatória e/ou Negatória. A socioafetividade, neste sentido, estaria intimamente associada ao princípio do melhor interesse da criança em ter preservado seu vínculo afetivo e social com seu pai. Todavia, consoante se observou no primeiro julgado em análise, a prevalência da socioafetividade estabelecida não ocorreu em decorrência do pai ter decidido se afastar quando teve ciência da infidelidade de sua companheira.

Ainda sobre as contradições inerentes as ações Negatórias, resgata-se, novamente, a contribuição de Cláudia Fonseca (2004) que refletiu sobre o paradoxo dos exames de DNA e sua insuficiência para a determinação da filiação destacando que "a afirmação de um fato biogenético, o cumprimento de uma lei e o desenvolvimento de uma relação social são processos distintos" . A autora apontou ainda que o uso da tecnologia genética como critério objetivo para determinação de paternidade poderia aparentar uma 'certeza', todavia, o resultado poderia dar margem à dúvida. O impasse se apresenta quando se percebe que os exames de DNA podem identificar o genitor, mas de maneira alguma conseguem revelar aquele que exerce a função paterna.

Por essas razões e dilemas, os doutrinadores inauguraram outra categoria conceitual, distinguindo o 'direito de filiação' do 'direito de conhecimento da origem genética', este último, direito personalíssimo e imprescritível. Vindica-se a origem biológica com o fundamento no princípio fundamental da dignidade humana. De acordo com Lôbo (2015), o propósito do exercício deste direito seria adotar medidas preventivas para preservação da saúde e da vida, e, portanto, não se admite confusão com a noção do estado de filiação, o qual advém de uma socioafetividade estabelecida no caso concreto. O entendimento de Lôbo, contudo, não alcança as Negatórias Clássicas amparadas pelo artigo 1.601 do Código Civil brasileiro, que, a exemplo do caso em análise, sequer mencionou o peso da socioafetividade no conflito entre o pedido do autor e o melhor interesse da criança.

Quanto às Ações Anulatórias, ganham destaque na argumentação do segundo julgado a voluntariedade e espontaneidade do registro, a despeito da ausência de vinculação biológica, e, a ausência de vício de consentimento no processo de reconhecimento público do vínculo de paternidade pelo Registro. Outra categoria analítica presente neste tipo de ação é o dever de assistência material pela prestação de alimentos a que o pai registral se vê obrigado enquanto não lograr se desvencilhar da paternidade. Neste aspecto, as questões das expectativas dos papéis de gênero, nos novos arranjos familiares, e no desempenho dos papéis de paternidade e masculinidade se presentificam. A postura do homem que assume os filhos de sua companheira, afirmando-se como provedor da prole e da casa afirma socialmente sua masculinidade e virilidade. Todavia, findada a relação, e em novo relacionamento, deseja desresponsabilizar-se do encargo outrora assumido, mesmo que a vinculação socioafetiva já esteja construída: "o homem reconhece como seus os filhos de uma

9 Ibid, p. 15. 
união anterior da esposa e, após o rompimento da parceria conjugal, encaminha o pedido de desconstituição da paternidade, com toda a amplitude da dimensão do termo". ${ }^{10}$

Na análise dos casos selecionados, a obrigação relacionada com o sustento dos filhos se insurge como uma categoria que também ilustra o que poderia ser tomado como 'amplitude' e 'dimensão' da socioafetividade. Ocorre no segundo julgado, a menção do relator sobre uma perspectiva omitida no primeiro caso. Respondendo ao pedido da Anulatória de Paternidade, o relator dá ênfase a provisão do sustento através da prestação alimentar como elemento que por si só já caracteriza uma das dimensões da filiação social:

No caso, a paternidade social explicita-se no dever de assistência material, comprovado nos autos que o apelado presta pensão alimentícia à apelante, que ainda não atingiu a maioridade. Não obstante a anulação do ato registral respectivo, o fato é impediente do direito à declaração de inexistência de vínculo parental entre as partes, pois o apelado é, sim, pai social da apelante, ao menos enquanto perdure a obrigação de lhe suprir alimentos, à míngua de prova da existência entre as partes de relações de outra natureza[...] (AREsp 653643 MG 2015/ooo9919-o, Relator Ministro Raul Araújo, DJe 09/04/2015)

O argumento do relator é construído considerando que o apelado seria o pai social da criança enquanto perdurasse a obrigação de lhe suprir alimentos. No entanto, estabelecendouma comparação entreos dois julgados, o quesito sustentoe manutenção da prole não parece ter tanta relevância na Negatória Clássica. Nesteúltimo caso, o peso maior é dado ao que ensejou fundamentou o registro: o vício no consentimento, visto que, a paternidade foi constituída a partir do 'erro' em consequência do companheiro ter sido 'supostamente' enganado pela mãe da criança. Neste sentido, pouco importa se a socioafetividade e a dependência econômica estiveram presentes nos primeiros cinco ou seis anos de convivência na relação paterno-filial.

Outra comparação possível de se estabelecer entre os dois julgados nasce a partir da linha argumentativa do segundo caso em análise. No pedido da Anulatória, o fato de o requerente alegar que não mantém mais relação afetiva com a criança ou sua mãe não é considerado motivo suficiente para o desfazimento das obrigações referentes à relação de filiação

O afeto é elemento de consolidação da relação parental, mas sua ausência não a descaracteriza. 5. Só a extinção do vínculo afetivo entre pais e filhos não os exime das obrigações e direitos legais derivados do poder/dever familiar[...] (AREsp 653643 MG 2015/ooo9919-o, Relator Ministro Raul Araújo, DJe o9/04/2015)

10 (Brito,2008, p. 8) 
No entanto, na Negatória, o fato do pai ter rompido com mãe e ter decidido se afastar da criança após o resultado do exame de DNA ter revelado a ausência de vínculo biológico com ela, respalda a priorização da proteção à honra subjetiva do homem traído em detrimento da proteção da relação parental consolidada em aproximadamente seis anos de convivência. No exemplo da Negatória, o desejo voluntário em afastar-se do filho, que registrou como seu, mostra-se uma estratégia suficiente para invisibilizar a hipótese de qualquer vinculação estabelecida, a ponto da incontroversa socioafetividade em questão sequer ser mencionada no julgado.

Ainda estabelecendo comparação entre os argumentos utilizados pelos relatores nos casos em análise, no caso da Negatória, há o registro da relevância da vontade e voluntariedade do pai em manter a relação parental como fundamento para a preservação da relação de filiação:

Ocorre que o estabelecimento da filiação socioafetiva perpassa, necessariamente, pela vontade e, mesmo, pela voluntariedade do apontado pai, ao despender afeto, de ser reconhecido como tal. (REsp 1.330.404-RS, Relator Ministro Marco Aurélio Bellizze, Terceira turma, julgado em 05/02/2015, DJe 19/02/20152

No entanto, no caso das Anulatórias, mesmo que os pais registrais aleguem que não desejam figurar como pai, ou seja, mesmo diante da explícita ausência de vontade e voluntariedade na manutenção do vínculo, o argumento não é aceito. Os pais registrais não logram se desobrigar com a mesma facilidade, uma vez que na ocasião do registro, quando se configura a adoção à brasileira, aqueles o fizeram de maneira voluntária e espontânea. E, mesmo que tenham se afastado do filho e constituído nova família, ou seja, sem que esteja preservada a atualidade do vínculo da socioafetividade, nem tampouco esteja presente a atualidade do desejo de manutenção do vínculo, a paternidade registral é mantida.

Neste ponto, resgata-se um trecho do argumento utilizado pelo relator no caso da Negatória Clássica (Caso 1):

[...] as manifestações de afeto e carinho por parte de pessoa próxima à criança somente terão o condão de convolarem-se numa relação de filiação se, além da caracterização do estado de posse de filho, houver, por parte do indivíduo que despende o afeto, a clara e inequívoca intenção de ser concebido juridicamente como pai ou mãe da criança. (REsp 1.330.404-RS, Relator Ministro Marco Aurélio Bellizze, Terceira turma, julgado em 05/02/2015, DJe 19/02/2015)

Neste ponto, vale a reflexão a respeito de outra categoria analítica: a voluntariedade do afeto. Estaria esta última tendo um peso maior que o próprio princípio do melhor interesse da criança? Ora, supõe-se que na ocasião do registro 
e durante o período de convivência com a criança, havia voluntariedade do pai em relação à manutenção do vínculo, mas, e, se o pai registral decide se afastar, 'deixar de cuidar e amar', onde fica o respeito ao interesse da criança e sua proteção integral? Ademais, destaca-se que o critério da vontade e voluntariedade da manutenção da paternidade tampouco é absoluto na paternidade biológica, visto que há filhos que são rejeitados pelo pais, crianças que crescem sem serem registradas, ou, que são registradas, mas crescem sem a convivência com seus pais, sem esquecer dos casos de abandono afetivo.

\section{Considerações finais}

A emergência do estado de filiação a partir do afeto passou a figurar como tema entre doutrinadores do Direito de Família:

[...] filiação social, filiação socioafetiva, estado de filho afetivo etc. Ditas expressões nada mais significam do que a consagração, também no campo da parentalidade, do novo elemento estruturante do direito das famílias. Tal como aconteceu com a entidade familiar, a filiação começou a ser identificada pela presença de vínculo afetivo paterno-filial. Ampliou-se o conceito de paternidade, que passou a compreender o parentesco psicológico, que prevalece sobre a verdade biológica e a realidade legal."

O reconhecimento legal das novas configurações familiares também recebeu destaque entre os estudiosos da área. Quanto ao peso do afeto enquanto critério de aferição da paternidade:

[...] simultaneamente ao crescimento do uso da tecnologia, tem aumentado também a consideração dos aspectos intencionais subjetivos dos indivíduos, dos afetos e sentimentos para a definição dos vínculos. Assim, tem ganhado espaço, dentre outras, a existência da paternidade / filiação socioafetiva. ${ }^{12}$

Nas demandas processuais em que estão presentes pedidos de investigação quanto à paternidade, de desconstituição da paternidade registral (ações anulatórias), regulamentação do direito de visita aos 'filhos de criação' e/ou enteados, e de reconhecimento voluntário de paternidade fundada no afeto, as decisões acerca do estado de filiação carecem de respeito ao critério do vínculo socioafetivo entre as partes. Verdade biológica ou socioafetiva, qual deve prevalecer quando houver conflito no caso concreto?

11 (Dias et. al., 2009, p. 324)

12 (Santos, 2010, p. 18) 
A proposta dediscussãoaqui presente, considerou odireito constitucionalmente asseguradoà crianças e adolescentes referente à convivência familiar. Buscou-se refletir sobre quais seriam os efeitos da desconsideração da socioafetividade na determinação do Estado de filiação em sua interlocução com o princípio que prioriza o melhor interesse da criança e do adolescente.

Vislumbrou-se que, no discurso Jurídico, os argumentos utilizados pelos julgadores do Superior Tribunal de Justiça, em duas ações distintas no mesmo ano, sustentaram posições divergentes quanto ao peso e consideração da socioafetividade. A reflexão trouxe à tona a discussão sobre a menção/omissão do melhor interesse da criança e do adolescente a partir das seguintes categorias: flexibilidade de alteração dos Registros de Nascimentos, atualidade da convivência paterno-filial, vontade e voluntariedade na manutenção do vínculo de filiação, provisão de alimentos para sustento e manutenção do filho, espontaneidade no registro de nascimento via 'adoção à brasileira', vingança, culpabilização da mulher e proteção à honra subjetiva do cônjuge traído, direito de desobrigar-se do papel de pai versus o direito do filho de ter seu status de filiação preservado.

Após a discussão e análise das categorias, as reflexões apontaram para descontinuidades na consideração da paternidade socioafetiva:

A paternidade socioafetiva é tomada em consideração de forma equilibrada ou primordial frente à paternidade biológica nos julgamentos das ações de adoção, guarda, visita [...]. Contudo [...] a paternidade socioafetiva é desconsiderada, ou tomada de forma marginal e secundária, nos julgamentos das [...] negatórias clássicas e anulatórias de falso registro..$^{13}$

Por fim, destacou-se ainda que a negligência aos vínculos socioafetivos estabelecidos, além de tornar marginal a socioafetividade, desprestigia o princípio do melhor interesse da criança e do adolescente nas ações Negatórias Clássicas.

\section{Referências}

AMARAL, Silvia Helena Santos do. (2013). No melhor interesse da criança e do adolescente: entre o cuidado, o controle, a proteção e a tutela - relatórios psicológicos em varas de família. Tese. (Programa Eicos - Programa de Pós-Graduação em Estudos Interdisciplinares de Comunidades e Ecologia Social) - Instituto de Psicologia, Universidade Federal do Rio de Janeiro - UFRJ.

13 (Portanova, 2018, p. 199) 
Brasil. Constituição da República Federativa do Brasil de 1988. (1988). Disponível em: http://www.planalto.gov.br/ccivil_03/constituicao/constituicaocompilado.htm. Acesso em: 17 de nov. de 2017.

Brasil. Lei no 8.069, de 13 de julho de 1990. (1990). Dispõe sobre o Estatuto da Criança e do Adolescente e dá outras providências. Disponível em: http://www.planalto.gov.br/ ccivil_03/leis/18069.htm. Acesso em: 17 de nov. de 2017.

Brasil. Lei n $n^{\circ}$ 10.406, de 10 de janeiro de 2002. (2002) Código Civil. Disponível em: http:// www.planalto.gov.br/CCivil_03/leis/2002/L10406.htm. Acesso em: 17 de nov. de 2017.

Brasil. Lei $n .{ }^{\circ} 11.340$, de 7 de agosto de 2006. (2006). Coíbe a violência doméstica e familiar contra a mulher. Presidência da República. Disponível em: http://www. planalto.gov.br/ccivil_03/_ato2004-2006/2006/lei/l11340.htm. Acesso em: 05 de janeiro de 2017.

Brasil. Superior Tribunal de Justiça. (2015). Recurso Especial: REsp 13300404/RS 2012/0127951-1. Relator: Ministro Marco Aurélio Bellizze. DJe: 19/02/2015.

Brasil. Superior Tribunal de Justiça (2015). Agravo em Recurso Especial: AREsp 653643 MG 2015/ ooo9919-o. Relator Raul Araújo. Disponível em: https://stj.jusbrasil. com.br/jurisprudencia/18oo92435/agravo-em-recurso-especial-aresp-653643mg-2015-0oo9919-o. Acesso em: 20 de novembro de 2017.

BRITO, Leila Maria Torraca de. (2008). Paternidades Contestadas. Belo Horizonte. Del Rey Editora.

CASSETTARI, Christiano. (2017). Multiparentalidade e Parentalidade Socioafetiva: efeitos Jurídicos. $3^{\mathrm{a}}$ ed. São Paulo: Atlas.

DIAS, Maria Berenice. (2017) Filhos do afeto: questões jurídicas. 2ª . Ed. São Paulo: Editora da Revista dos Tribunais.

DIAS, Maria Berenice; BASTOS, Eliane FERREIRA e MORAES, Naime Márcio Martins. (Coords). (2009). Afeto e estruturas familiares. $1^{\underline{a}}$ ed. Belo Horizonte: Del Rey.

FONSECA, Cláudia. (2004). A certeza que pariu a dúvida: paternidade e DNA. Estudos Feministas. 12(2): maio-agosto, 13-34. Disponível em: http://www.scielo.br/scielo. php?script=sci_arttext\&pid=So104-026X2004000200002\&lng=en\&nrm=iso\&tlng=pt. Acesso em: 20 de março de 2018.

FOUCAULT, M. (2010). Os anormais: curso no Collège de France. [1974-1975]. São Paulo: Martins Fontes. 
LÔBO, Paulo Luiz Netto. (2004). "Direito ao estado de filiação e direito à origem genética: uma distinção necessária." In: Conferência proferida no 'II Encontro de Direito de Família do IBDFAM/DF', realizado pelo Instituto Brasileiro de Direito de Família - Seção Distrito Federal, de 10 a 14 de maio de 2004, no auditório do Superior Tribunal de Justiça, em Brasília - DF. Disponível em: www.cjf.jus.br/ojsz/index.php/ revcej/article/viewFile/633/813. Acesso em: o5 de novembro de 2017.

LÔBO, Paulo. (2013). Socioafetividade em família e a orientação do STJ. Revista Jus Navigandi, ano 18, n. 376o, 17 out. 2013. Disponível em: https://jus.com.br/ artigos/25365. Acesso em: 05 nov. 2017.

LÔBO, Paulo. (2015) Direito Civil: famílias. 6ed. São Paulo: Saraiva.

PEREIRA, Rodrigo da Cunha. (2012). Princípios fundamentais norteadores do direito de família. 2. ed. São Paulo: Saraiva.

PORTANOVA, Rui. (2018). Ações de filiação e paternidade socioafetiva. zed. Porto Alegre: Livraria do Advogado.

SANTOS, Dayse Amâncio dos. (2010). Aqui a Gente Administra Sentimentos: Famílias e Justiça no Brasil Contemporâneo. Tese (Doutorado em Antropologia) - Universidade Federal de Pernambuco. Recife.

SILVEIRA, Paula Galbiatti. (2011) A doutrina da proteção integral e a violação dos direitos das crianças e adolescentes por meio de maus tratos. Instituto Brasileiro de Direito de Família. Disponível em: www.ibdfam.org.br/_img/artigos/A\%2o doutrina\%2017_11_2011.pdf. Acesso em: 19 de nov de 2017.

Recebido: 27.03.2018

Aceito: 29.06.2018 